\title{
Ion Barbu: "Pădurile noastre au fost gestionate de așa manieră încât diversitatea biologică s-a menținut la cote maxime. În Car- pați se află poate singurele păduri dìn Europa în care piramida trofică și prezența tuturor formelor de viațăa a rămas nederanjată"
}

\section{Laurențiu Biornei}

"Optimist, profund, pasionat, muncitor, charismatic" - sunt doar câteva dintre însușirile pe care i le-a atribuit un mare profesor și deosebit silvic lui Ion Barbu. La acestea s-ar mai putea adăuga încă multe, toate simbolizând profesionalismul și abilităţile doctorului Barbu pe care acesta le-a dovedit în cercetarea științifică dedicată pădurii.

L-am perceput pe dr. Barbu ca pe un chirurg. Critic, exigent, deosebit de realist, dumnealui nu se sfiește să arate tumoarea și să insiste pentru îndepărtarea acesteia. Prezintă și soluții, fapt remarcabil, în zilele noastre, chiar și pentru specialiștii silvici care încă mai caută vinovați decât rezolvări.

Ion Barbu ar trebui considerat drept cercetătorul științific care, în silvicultura românească, are voință de adevăr. Curios și, deopotrivă, înțelept, Ion Barbu excelează în a vedea pădurea dincolo de bine și de rău, fiind mereu în avanposturile cunoașterii, dar și un împătimit al diseminării acesteia. Urcă des în Călimani, face singur toate măsurătorile, rapoartele și analizele de mediu care sunt necesare pentru buna conservare a biodiversității Parcului, unde este membru în consiliul științific.

Ion Barbu mai are o calitate, o floare rară chiar și printre silvici: este un foarte bun camarad. De peste o jumătate de secol este prietenul cel mai bun a deosebitului profesor Radu Cenușă.

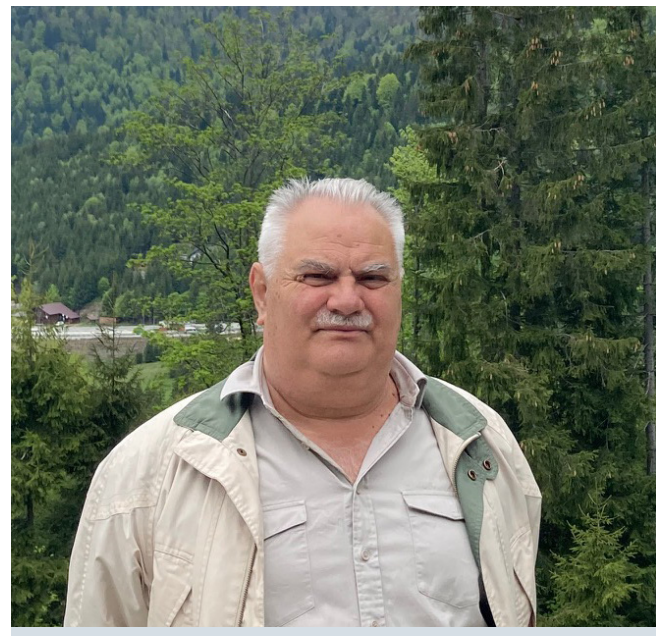

Dr. ing. Ion Barbu

Dr. eng. Ion Barbu

Ion Barbu s-a născut, acum 69 de ani, în inima Deltei Dunării, în satul Sarinasuf. Fascinat de păduri și de cunoaștere s-a înscris la Facultatea de Silvicultură din Brașov, pe care a absolvit-o, ca șef de promoție, în 1976. De atunci, cu mici excepții, a lucrat în cercetarea științifică, la Stațiunea Experimentală de Cultură a Molidului din Câmpulung Moldovenesc. A publicat mai bine de 100 de articole științifice, cărți și monografii în reviste și publicații de prestigiu internațional. Cadru didactic universitar cu personalitate, Ion Barbu a condus și coordonat numeroase proiecte de cerectare internaționale. Doctor, din 1982, în silvicultură cunoaște engleză, germană și franceză. 
1. Cum a ajuns un copil al Deltei să fie vrăjit de pădurile de munte?

Într-adevăr, m-am născut în Delta Dunării, la Murighiol, și am văzut de mic copil pădurile-galerii de sălcii și plopi care însoțeau malurile brațului Sfântu Gheorghe și ale canalului Dunavăț. Adesea, după ce ne plictiseam de pescuit, mergeam să explorăm pădurea. Acolo erau sălcii mari cu diametre de peste doi metri cu scorburi uriașe, în care ne făceam adevărate locuri de supraviețuire. Încet, încet, diversitatea pădurii m-a fascinat şi am dorit să cunosc şi alte păduri. În vacanțele de vară, părinții noștri ne trimiteau la mare, la Sulina, și la munte, la Babadag. Pădurile Babadagului au fost primele mele descoperiri cu adevărat ale diversității unei păduri pe un relief accidentat pentru că pădurile Deltei sunt păduri aluviale, cu o structură aparte. Ulterior, am văzut pădurile montane ale țării, la început în taberele pionierești, și îmi amintesc cu mare plăcere de pădurile din jurul Văii Oltului, din Munții Lotrului mai ales de la Cozia, iar ca student am descoperit pădurile din jurul Brașovului.

\section{Din punctul de vedere al calității și structurii cum a} evoluat pădurea românească în ultimii o sută de ani? Evoluția pădurii românești în ultima sută de ani este spectaculoasă, dacă ne gândim că la sfârşitul Primului Război Mondial pădurea românească era fărâmițată, sub raportul proprietății, iar cea montană greu accesibilă, mai ales din cauza lipsei mijloacelor de transport la distanță a masei lemnoase. Analiza datelor statistice existente pentru pădurile României la începutul secolului XX evidenţiază o mare diversitate a stării acestora. Cel mai adesea, pădurile accesibile din zona de câmpie și colinară care erau tratate în crâng, adică se regenerau din lăstari, acestea fiind folosite mai ales pentru obținerea lemnului de foc și a lemnului de mici dimensiuni pentru construcții rurale. La munte erau, în cea mai mare parte, păduri virgine, neafectate de tăieri masive și în marea lor majoritate, inaccesibile. Analiza evoluției pădurilor în ultima sută de ani se poate face relativ simplu atât la nivel național, cât și la nivel local, deoarece beneficiem de informații foarte detaliate cuprinse în ceea ce numim generic amenajamentul silvic. Amenajamentul silvic este un studiu care permite organizarea spaţio- temporală a pădurii cu scopul unei gestionări raționale pe baza principiului de bază al silviculturii, asigurarea continuității. Astăzi îi spunem asigurarea sustenabilității sau a durabilității pădurilor. Este un termen nou, modern, care a fost vehiculat mai ales după Reuniunea de la Rio din 1992. În prezent, pregătesc o lucrare care tratează evoluția pădurilor României după cel de al Doilea Război Mondial, mai bine spus după etatizarea acestora, în care analizez, pe baza de documente, atât politice, cât și tehnice, evoluția caracteristicilor structurale și funcționale ale pădurilor în această perioadă. Iată, sunt aproape 75 de ani de când pădurile țării au fost etatizate şi gestionate ferm, prin amenajamente silvice. După 1990, numeroasele legi care au reconstituit proprietatea asupra pădurilor au determinat modificări esenţiale în starea și caracteristicile structurale și funcționale ale pădurilor actuale. Au trecut 30 de ani de la Legea 18/1991 și putem să analizăm ce a adus bun și cea a adus rău privatizarea pădurilor pentru funcționalitatea acestora, considerând că pădurile sunt un bun național, de interes general, care asigură un mediu sănătos și o protecție împotriva hazardelor climatice, în principal. Revenind însă la întrebarea dumneavoastră, pe ansamblu putem spune că pădurea românească a crescut, atât sub raportul suprafeței ocupate, cât și sub raportul calității acesteia. Nu putem generaliza peste tot, dar în principal, putem spune că suprafața pădurilor țării a crescut simţitor în primul rând prin integrarea în fondul forestier a numeroaselor terenuri degradate care au fost împădurite prin efortul inginerilor silvici și în al doilea rând prin integrarea în fondul forestier a unor numeroase suprafețe ocupate anterior de pășuni împădurite sau pășuni abandonate - în zona montană - care au evoluat spre o structură de pădure, la început prin specii pioniere şi ulterior specii prin- 
cipale, unele dintre acestea chiar importante economic. Sub raportul calității, putem aprecia că pădurile țării au făcut un progres în ceea ce privește frecvența speciilor valoroase pentru industria lemnului, dar aici există multe semne de întrebare în ceea ce privește frecvența daunelor produse arborilor din păduri ca urmare a exploatării neraționale a lemnului, folosind tehnologii neadecvate în principal tractoare de mare putere și în al doilea rând din cauza pagubelor produse în anumite zone ale țării de supraefectivele de vânat. Înmulțirea vânatului ierbivor, în principal cervide, în perioada anilor 1960-1990 a determinat pagube majore în pădurile de amestec, în special la speciile sensibile cum sunt bradul, paltinul de munte și molidul. Păstrarea unui echilibru între componentele pădurii este esențială pentru asigurarea unei calități cât mai ridicate atât a arborilor, cât și a vânatului. Exemplul pe care l-am prezentat, poate fi servit drept lecție pentru modul în care trebuie gestionat vânatul, astfe încât efectivele acestuia să nu determine o pierdere calitativă şi cantitativă a arborilor din pădure. Reglarea raporturilor dintre componentele piramidei trofice este esenţială pentru asigurarea acestui echilibru, iar în ultimele decenii asistăm la o creștere alarmantă a frecvenței carnivorelor mari urs, lup, râs și, în ultima vreme, șacal, în special și în zonele de câmpie și de deal, care determină pagube imense în sectorul forestier, dar în ultima vreme în sectorul privat, fără o intervenție fermă care să conducă la echilibrarea raporturilor dintre componentele ierbivore și carnivore ale mediului natural. Vom avea în continuare probleme deosebite care se vor repercuta asupra confortului și standardului de viață al populației.

\section{Cum a devenit Bucovina țara fagului?}

Într-adevăr, în traducere, Bucovina ar însemna țara fagilor, dar acest termen este, aşa cum s-a mai spus, neconcordant cu compoziția pădurilor din zona, dominate de brad și de molid. Termenul Bucovina a fost generalizat și impus politic după 1775 , când austriecii au ocupat această parte a Moldovei pe care au numit-o inițial Nordmoldau, iar pe vremea lui Ștefan cel Mare se numea Țara de sus. Pentru a se pierde urma țării din care a fost răpită aceasta provincie, administrația militară austriacă a generalizat acest toponim binecunoscut în toată zona slavă a Europei. Bucovina, Bucoveanu, Bucovăț înseamnă o zonă colinară acoperită de păduri de fag. Lângă Cernăuți avem dealurile cunoscute cu numele Bucovinele Mari și Bucovinele Mici. Niciodată nu a fost numită țara fagilor de către populația locală, dar în ultima vreme s-a generalizat termenul de Bucovina și foarte mulți sunt mândri de această denumire. Pe vremea luptei pentru emanciparea populației românești din zonă și ne amintim acum de "Arboroasa", o societate a studenților români din Cernăuți, care a luptat pentru o Independență a Bucovinei și pentru afirmarea drepturilor românilor în această provincie a Imperiului austriac, ei denumeau aceasta provincie cu acest nume. "Arboroasa" a fost, de asemenea, un nume creat-artificial, dar mult mai adecvat având în vedere ponderea pădurilor în suprafaţa ducatului Bucovinei.

\section{Tendințe în cercetarea științifică forestieră. Care sunt prioritățile?}

În contextul actual, prioritățile cercetării științifice sunt multe. În ceea ce privește tendințele, aici ar fi de discutat mai multe aspecte: în primul rând tendința de a copia teme și programe de cercetare care sunt bine finanțate atât la nivel european, cât și la nivel național, pornind de la niște priorități care au fost definite de altcineva şi nu de un consorțiu format din reprezentanţi ai economiei forestiere și aici mă refer la silvicultură, la exploatarea pădurilor, la industrializarea lemnului, la gestionarea rezervațiilor şi a parcurilor naționale la gestionarea siturilor Natura 2000 și, de ce nu, la schimbările globale. Ca să faci cercetare științifică ai nevoie, în primul rând, de personal calificat! Ceea ce constatăm în ultima vreme este lipsa tinerilor dornici să vină în activitatea de cercetare științifică şi să se specializeze într-un domeniu. Ce 
observ eu în ultimii ani, chiar în ultimii 20-30 de ani, este dorința tinerilor de a obține cât mai repede un titlu de doctor și de a pleca sau de a obține un post mai bun într-un domeniu care nu mai are de a face cu activitatea de cercetare. Modul actual în care se face promovarea doctoranzilor şi a tezelor de doctorat este, de asemenea, discutabil, iar sub raportul calității de multe ori inferior unor lucrări de diplomă sau de licență de altădată! Nu intru în analiza cauzelor, dar se pare că schimbarea macazului prin adoptarea sistemului Bologna nu a adus prea multe lucruri bune în acest domeniu. Revenind la cercetarea științifică în domeniul silvic, trebuie să spunem că de cele mai multe ori sunt finanțate programe de cercetare fundamentală. Competența și capacitatea Institutului nostru (n.r. INCDS „Marin Drăcea”) de a participa la realizarea unor asemenea proiecte este relativ redusă și, din această cauză, finanțările se obțin greu. La ora actuală, domeniul forestier are nevoie de o cercetare aplicată care să ofere soluții la problemele stringente actuale, în primul rând este vorba de dezvoltarea cercetărilor în domeniul general al protecției pădurilor. Factorii abiotici, între care seceta, arșiţa, deshidratările din timpul iernii, doborâturile de vânt și rupturile de zăpadă au fost în mare parte abandonate sau subfinanțate în ultima perioadă. În al doilea rând, apariția unor specii invazive de insecte dăunătoare și de ciuperci determină uneori pierderi importante ale potențialului de producție al pădurilor; finanțarea unor asemenea proiecte de cercetare cu finalitate imediată ar fi de natură să apropie pe de o parte cercetarea de producția silvică, iar pe de alta parte, să contribuie efectiv la îmbunătăţirea stării pădurilor. Fără îndoială, este necesar să se discute, într-un consorțiu de grupuri interesate priorităţile și modul de realizare a finanțării. De asemenea, consider că e necesar controlul modului în care s-au cheltuit banii. De cele mai multe ori temele se finalizează cu articole publicate, dar cu foarte puține recomandări practice. Fuga cercetătorilor după publicații în reviste recunoscute face ca, adesea, tematica articolelor să copieze tematici 96 similare acceptate în revistele respective, în dorința sau în speranța că vor obține publicarea cât mai rapid. Fără o obiectivitate a cercetărilor la specificul pădurilor țării noastre, nu vom face decât să „,confirmăm” ceea ce au spus alții. Astăzi, prioritatea priorităților rămâne însă cercetarea capacității speciilor de a se adapta la schimbările globale. În primul rând la schimbarea structurii pădurilor, deoarece asistăm tot mai mult la tăieri rase și cvasirase pe suprafețe tot mai mari, cu toate limitările legale, astfel încât speciile trebuie să se regenereze în teren deschis sub influența insolației și a extremelor climatice. Studiul capacitații speciilor de a ocupa anumite nișe ecologice, care se modifică sub influența încălzirii globale, fără experimente instalate în condiții staționale cât mai diverse, nu este posibil. Acestea trebuie urmărite pe o perioadă cât mai îndelungată de timp şi, în acest fel, vom obține rezultate capabile să ajute pădurile noastre. Astfel de proiecte ar trebui să fie finanțate în mare parte din generosul Program Național de Redresare și Reziliență, în care rolul pădurilor pentru tamponarea efectului de seră, ca urmare a absorbției $\mathrm{CO}_{2}$ din atmosferă și pentru îmbunătățirea modului de utilizare a terenurilor, este esențial.

\section{Pădurea românească are potențial și valoare. Bio- diversitatea este încă la cote superioare, deosebite, iar mulți ne invidiază. Ce ne puteți spune din punct de vedere al viitorului? Sună acesta bine?}

Este adevărat că pădurea românească, prin marea sa diversitate și prin gradul ridicat de naturalitate - comparativ cu pădurile din alte țări europene - are un mare potențial și o valoare genetică deosebită. Trebuie însă să fim deosebit de atenți la modificările pe care silvicultorii le aduc zi de zi structurii și funcționalității pădurilor prin forțarea tăierilor rase, urmată de împăduriri cu specii, proveniențe sau ecotipuri neadecvate. Procedând astfel, nu facem decât să slăbim naturalitatea și stabilitatea viitoarelor păduri. În ultimele decenii, s-a observat o tendinţă de extindere a tăierilor în pădurile situate la altitudini mari, de peste 1.300-1.500 de metri, în etajul molidișurilor, acolo unde riscul 
amplificării efectelor climatice extreme, specifice pădurilor de limită este maxim. Dacă nu vom adopta tratamente bazate pe regenerarea naturală şi menținerea ecotipurilor adaptate acestor altitudini, riscăm să creăm artificial arborete cu o valoare genetică redusă, neadaptate condițiilor climatice specifice zonei. Cercetările internaționale, reluate și în laboratoarele noastre, pentru testarea valorii genetice a pădurilor din țara noastră au evidențiat un potențial genetic deosebit de valoros, bine adaptat care trebuie menținut și amplificat. În ceea ce privește biodiversitatea trebuie menționat că pădurile noastre au fost gestionate de așa manieră încât diversitatea biologică s-a menținut la cote maxime. În Carpaţi se află, probabil, singurele păduri din Europa în care piramida trofică și prezența tuturor formelor de viață a rămas nederanjată. Existența unei cantități importante de lemn mort oferă nișe ecologice pentru menţinerea unor specii de insecte și ciuperci care în multe părți din Europa au dispărut demult. Menținerea diversității biologice reprezintă o componentă importantă a programului de gestionare rațională a pădurilor din România, iar alternanța unor petice (subparcele) de păduri de vârste diferite, cu compoziții diferite, cu stratificare pe verticală diferită este o garanţie a reuşitei programelor de gestionare pentru conservarea diversității biologice. $\mathrm{Cu}-$ noaștem că, an de an, experți în diferite grupe de forme de viață găsesc în pădurile din România - nu numai în rezervații - o serie de specii şi varietăți de insecte și plante care în Europa au dispărut de mult, unele chiar de sute de ani, ca urmare a modificărilor radicale în structura compozițională și funcțională a pădurilor din aceste țări (Germania, Cehia, Polonia, Belgia, Țările de Jos etc.). Testele internaționale de proveniență cu specii care s-au dovedit extrem de sensibile în Europa, precum bradul, fagul, ulmul, frasinul, evidenţiază că ecotipurile din țara noastră pot fi utilizate cu succes în reconstrucția ecologică a unor întinse zone forestiere din Europa centrală și de vest, unde, urmare a acțiunii continue şi îndelungate a poluării și altor stresori care au acționat de-a lungul secolelor, pădurea a fost destabilizată până la dispariția locală a unor specii. Perspectiva unui export masiv de material genetic din țara noastră, în special din Carpați, există și consider că va oferi o bună ocazie de a demonstra Europei superioritatea soluțiilor de management forestier pentru pădurile din Carpați comparativ cu cele din alte regiuni ale Europei.

\section{Silvicultura românească și tehnologia. Nu suntem prea dornici să investim în noile tehnologii, în ele- mente de Inteligență Artificială, și cam batem pasul pe loc în multe dintre sectoarele industriei dezvolta- tă pe umerii pădurii. Ce anume sau cine ar putea să rupă această vrajă nefericită care obligă silvicii să folosească metode și utilaje învechite? Sau poate că aceasta se dorește?}

În gestionarea pădurilor şi mai ales pe lanțul de transformare a produselor pădurii este necesară, chiar indispensabilă, mecanizarea, automatizarea și, de ce nu, informatizarea. Pătrunderea tehnologiilor specifice în aceste domenii s-a făcut cu sincope și cu rezultate diferite. Să vă explic: analiza potențialului de extindere a unor tehnologii moderne trebuie făcută diferențiat, în funcție de domeniul la care ne referim. Dacă ne referim la silvicultură trebuie să analizăm posibilitatea de a introduce mecanizarea și automatizarea în procesele specifice regenerării și conducerii pădurilor și anume: în producția și conservarea semințelor, în producția de puieți și material genetic ameliorat pentru regenerarea artificială a pădurilor, în combaterea bolilor și dăunătorilor specifici diferitelor formații forestiere și, nu în ultimul rând, în supravegherea stării de sănătate a pădurilor.

În domeniul exploatării mase lemnoase a fost o perioadă, în anii 70-90, în care mecanizarea, diversificarea tehnologiilor de exploatare a lemnului în funcțiile de condițiile fizico-geografice, în special în zonele cu teren accidentat, au luat o mare amploare. Colectarea masei lemnoase cu funiculare, utilizarea instalațiilor cu cablu, precum și modernizarea transporturilor au reprezentat o realitate. S-au construit în această perioadă circa 30 de mii 
de $\mathrm{km}$ de drumuri realizate de experți forestieri pentru accesibilizarea pădurilor. Acestea reprezintă realizări de mare tehnicitate și care au generat o rentabilitate economică deosebită, cu care ne mândrim. Din păcate, în ultimii ani asistăm la o degradare a tehnicității și tehnologiilor utilizate în exploatarea pădurilor, în locul instalaţiilor pe cablu fiind folosite preponderent tractoarele. Impactul pe care colectarea cu tractoare - în anumite condiții - îl are asupra solului, asupra arborilor rămași, a regenerării este major și din păcate insuficient cercetat. O analiză economică serioasă ar pune în evidență dezavantaje majore ale utilizării tractoarelor la colectarea masei lemnoase și ar conduce la interzicerea acestora pe mari suprafețe.

În domeniul industrializării lemnului trebuie să menționăm următoarele: în perioada 1950 -1980 s-a dezvoltat o industrie de valorificare a lemnului și a produselor pădurii de la colofoniu la fructe de pădure și de la rășină la cetină care au generat produse naturale cu utilizare îndelungată de o calitate excepțională atât pentru necesarul intern, cât și pentru export. A existat o dimensionare echilibrată între potențialul de producție al pădurilor și capacităţile de valorificare a tuturor sortimentelor de lemn pe care acestea îl pot produce. Din păcate, în ultimii 20-30 de ani am asistat la distrugerea aproape integrală a Industriei lemnului, în prezent nefiind capabili să producem nici măcar hârtie igienică și/sau hârtie de ziar.

În domeniul cercetării științifice, tehnologiile și echipamentele pentru investigarea proceselor specifice care au loc în arbori, în principal procesele fiziologice și ecofiziologice de producere a fotosintezei, a respirației și transpirației, mai ales de investigare a impactului factorilor stresori asupra acestor procese, au căpătat pondere importantă și multe dintre laboratoarele noastre sunt dotate cu echipament comparabil cu cel din țările europene vecine. Participarea cercetătorilor din țara noastră la programe de cercetare internaţionale europene cum este programul I.C.P. Forest. Un program de evaluare a impactului poluării transnaționale asupra pădurilor au determinat un plus de 98 calitate în analizele de laborator și în interpretarea rezultatelor pe baza unei abordări interdisciplinare holistice. Aș vrea să menționez că fără o dezvoltare echilibrată a tuturor componentelor lanţului de gestionare, industrializare, valorificare și transformare a lemnului și altor produse care să genereze locuri de muncă și să asigure dezvoltarea prin valorificarea potențialului de producție durabilă al pădurii nu vom putea realiza progrese semnificative în gestionarea fondului forestier. O dezvoltare echilibrată atrage după sine creșterea rentabilității și în măsură egală a gradului de mecanizare și automatizare a unor procese strict necesare. Asistăm la un proces de migrație masivă a populației din zona montană către oraș și mai ales către diferite țări ale Europei și ne confruntăm, pe zi ce trece, cu o criză a forței de muncă și în special a forței de muncă de înaltă calificare necesară în toate lucrările silvotehnice, de valorificare a lemnului şi de industrializare a acestuia. Trebuie să facem eforturi pentru păstrarea forței de muncă și pentru crearea locurilor de muncă necesare stabilizării populației, numai în acest fel vom contribui la ceea ce numim generic "dezvoltarea durabilă" a țării.

\section{Care sunt cele mai mari amenințări la adresa pă- durii românești și care ar fi metodele cele mai optime pentru evitarea unor situații neplăcute?}

Putem aprecia că, în prezent, România este o colonie care produce doar materii prime, valorificate de firme străine sau multinaţionale, implantate pe teritoriul nostru și este consumatoare de produse finite venite din import. $\mathrm{Nu}$ trebuie să ne mire deficitul de balanță comercială. Dacă avem în vedere prețurile derizorii pentru materiile prime și prețurile comparative cu cele din vestul Europei pentru produsele finite importate, explicația vine de la sine. Aceasta este probabil cea mai mare amenințare pentru România. Pentru pădurea românească, amenințarea cea mai mare o constituie goana după materia primă principală pe care o produce pădurea, lemnul. Singurul sortiment de lemn solicitat de majoritatea firmelor străine este lemnul de calitate superioară, lemnul de 
cherestea, toate celelalte sortimente de lemn nu au cerere din cauza distrugerii Industriei autohtone a lemnului care altădată valorifica sortimentele inferioare de lemn pentru producția de celuloză de PAL, PFL, panel, fibră artificială, mătase artificială și așa mai departe. Căderea Industriei lemnului a determinat nu numai o reducere drastică a locurilor de muncă, dar și o rentabilitate redusă a economiei forestiere pe ansamblu, ponderea în PIB a economiei forestiere a scăzut de circa cinci ori în ultimii 30 de ani. Aceasta este o cifră care trebuie să ne îngrijoreze. Goana după lemn determină proprietarii de păduri şi administratori pădurilor de stat la recolte din ce în ce mai mari pentru a acoperi cheltuielile pe de o parte și pentru a satisface cererile firmelor menționate și ale decidenților politici. Pe de altă parte, populația locală este neglijată total, prețul lemnului de foc ajungând la valori prohibitive. Aceasta explică de ce frecvent înregistrăm conflicte între populaţia locală și administratorii pădurilor. Statul nu a făcut nimic pentru a asigura accesul în condiții corecte la resursa lemn de foc pentru populația rurală. Cunoaștem că peste jumătate din populația României folosește ca singura sursă de energie pentru încălzire și pentru gătit lemnul de foc. Acesta trebuie să fie o servitute gratuită pentru populația de la țară, îmbătrânită și cu venituri tot mai reduse. Dacă pentru populația orășenească s-au făcut investiții în asigurarea rețelelor de gaz, de termoficare, de canalizare de electricitate, internet și așa mai departe, pentru populația de la tară aceste investiții sunt încă minore.

O altă amenințare importantă o reprezintă abandonul terenurilor forestiere private, de pe care s-a recoltat lemnul și care nu au fost regenerate corect. Evoluția pădurilor de pe aceste terenuri se face prin regenerare cu specii pioniere, de valoare redusă (mesteacăn, plop tremurător, carpen, tei în funcție de regiunea biogeografică) cu impact major pentru calitatea pădurilor viitoare.

În final, aș vrea să menționez o birocratizare excesivă a silviculturii prin producția masivă de hârtii, adesea fără relevanță pentru modul de gestionare al pădurilor. Deși în structura Ministerului Mediului și al Regiei Naţionale a Pădurilor există numeroase organisme de control, eficiența acestora este deosebit de redusă, de cele mai multe ori controalele în teren realizându-se în baza unor reclamații -de multe ori nefondate- ale concurenței. Problemele reale de gestionare a pădurilor sunt neglijate sistematic, controlul vizând doar cioatele și eventualele tăieri ilegale. Se verifică încă o dată adagiul binecunoscut "controlorii nu văd pădurea din cauza copacilor".

\section{8. "Teoria diagnosticului anticipat". S-a renunțat la această practică?}

$\mathrm{Nu}$ aş prea vrea să mai vorbesc de această problemă. Din păcate, mulți dintre colegii noștri ignora greșelile din trecut și riscă să le repete. Trimit cititorii interesați la cărțile clasice și publicațiile din perioada anilor 50-70, când această temă era dominantă în literatura de specialitate. După 1961, în planurile de amenajare a pădurilor existau capitole separate care se refereau la culturi speciale pentru celuloză și colofoniu și la substituirea arboretelor slab productive și înlocuirea acestora, de regulă, cu specii repede crescătoare pini, molid, douglas, plop negru hibrid, salcie ameliorată și așa mai departe. Teoria diagnosticului anticipat s-a aplicat intens până la jumătatea anilor 80, când observându-se eșecul transformării radicale a pădurilor după metoda consacrată, care viza extinderea rășinoaselor în afara arealului lor natural și creșterea ponderii acestora de la circa $25 \%$ la $40 \%$ din întinderea pădurilor țării, și s-a trecut la adoptarea unei alte legi care viza gestionarea rațională a fondului forestier bazată pe valorificarea potențialului natural al ecosistemelor. Efectul acestor programe, insuficient fundamentate, de transformare a naturii prin înlocuirea pe suprafețe mari a speciilor natural fundamentale cu specii neadaptate sau vulnerabile a determinat pe de o parte cheltuieli enorme, estimate la vremea respectivă chiar de către promotorul acestor idei la circa două miliarde de euro, și la dificultăți insurmontabile în gestionarea unor astfel de 
păduri. Crizele prin care trec pădurile din zona submontană și colinară, precum și pădurile din zona luncilor inundabile ale Dunării și râurilor interioare, fac din când în când, obiectul unor dezbateri, din păcate fără finalitate.

9. În România, din perspectiva serviciilor ecosistemice nu prea sunt sentimente comerciale. Proprietarii de păduri, inclusiv statul, nu beneficiază de susținere financiară pentru respectivele servicii, deși tendința internațională indică un sens favorabil pentru plata acestora. Care ar fi soluțiile pentru ca România să se încadreze și în această normalitate?

Desigur, este modern astăzi să vorbim de dezvoltare durabilă, să vorbim despre plata unor servicii ecosistemice, dar, din păcate, acestea sunt doar vorbe goale care nu au încărcătura necesară pentru a deveni funcționale. Pădurile au a fost dintotdeauna generatoare de bunuri şi servicii, dar doar recent, după Reuniunea de la Rio din 1992, factorii politici au conștientizat valoarea ecoprotectivă pe care o au pădurile globului şi faptul că acestea, prin procesul de fotosinteză, generează oxigen și absorb $\mathrm{CO}_{2}$, mențin aerul curat, contribuie la stabilitatea și regenerarea solurilor, asigură un circuit echilibrat al apei în natură. Pe lângă serviciile sociale din ce în ce mai apreciate de populația tot mai urbanizată a lumii, pădurile generează bunuri valorificabile pe care într-un cuvânt le numim materii prime regenerabile. În primul rând, lemnul și în al doilea rând produsele nelemnoase ale pădurii. Valorificarea principalelor produse ale pădurii prin industrializare în produse finite cu o plusvaloare adăugată importantă, generează nu numai locuri de muncă și prosperitate, dar generează stabilitate și condiții optime pentru generațiile viitoare. În ceea ce privește plata serviciilor ecosistemice s-a purtat o discuție, și încă se mai poartă, dar din păcate, după părerea mea, este departe vremea când serviciile ecosistemice generate de pădure vor fi plătite în vreun fel. Singurul produs al pădurii care are o anumită valoare este lemnul și produsele nelemnoase valorificabile. Rolul pădurilor în menținerea funcționalități și numeroaselor lacuri de baraj din țara noastră este indiscutabil și deși producția de energie electrică a fost privatizată nimeni încă nu a plătit un cent pentru serviciul hidrologic major pe care pădurile îl exercită în beneficiul celor care au devenit stăpânii producției de energie electrică în țara noastră. Este doar un exemplu și aş putea continua cu necesitatea compensării proprietarilor de păduri ale căror suprafețe cad în zonele strict protejate ale parcurilor naționale și parcurilor naturale din țara noastră. De aproape 30 de ani există promisiunea că aceștia vor fi compensați, dar rămâne o simplă promisiune. Normalitatea o constituie bunul simț de a lăsa silvicultorii să își facă meseria pe baza științelor silvice și a doctrinelor verificate de sute de ani în gestionarea rațională și durabilă a pădurilor și de a accepta că tăierea unor arbori (resursă regenerabilă) nu reprezintă nici defrișare, nici atentat la biodiversitate, ci reprezintă o componentă din lungul șir al lucrărilor de gestionare durabilă a pădurilor, în beneficiul generației actuale și al generațiilor viitoare.

10. Mai este molidul românesc arborele de pâine? Tot mai des rezistența, temperată, a molidului este pusă la grele încercări ale unor mulțimi de factorilor pertubatori. Cum vor duce silvicii această cruce?

$\mathrm{Da}$, am folosit pentru o prezentare sintagma „molidul-arborele de pâine al industriei forestiere" traducând termenul german „Brotbaumfichte". Da, în continuare molidul este specia cea mai importantă pentru industria lemnului. Din păcate, în beneficiul străinilor, cu consecințele binecunoscute. Este dureros că potențialul de producție al pădurilor României cu o paletă largă de calități, de la lemnul de rezonanță și de claviatură la lemnul de celuloză, nu mai generează bunăstare şi bogăţie pentru populația României, care în absenta locurilor de muncă a fost silită să emigreze. Așa cum am mai spus, pădurile de molid de ale României - şi nu sunt puține, doar în zona montană în etajul molidului avem aproape 1,3 milioane de hectare- necesită lucrări de conducere și de 
asigurare a unei stabilități maxime la acțiunea factorilor perturbatori, în principal a zăpezii și a vântului. Arătam anterior că neglijarea unor lucrări de îngrijire în tinerețe, în principal curățiri și rărituri, și păstrarea unor densități exagerat de mari în primii 30 și 40 de ani de viață a arboretelor fragilizează pădurile de molid și le fac vulnerabile la acțiunea factorilor perturbatori. Fără îndoială că există soluții! Cercetările experimentale pe care le-am condus în ultimii 40 de ani au evidențiat soluțiile clare de creștere a stabilității pădurilor de molid în condițiile artificializării lor. Enumăr doar câteva dintre acestea:

i) Plantarea la scheme mai rare, $2.000-2.500 \mathrm{de}$ puieți pe hectar în zonele neregenerate natural;

ii) Păstrarea nucleelor de regenerare naturală și introducerea speciilor însoțitoare ale molidului bradul, fagul, paltinul de munte cu scopul măririi spațiului de înrădăcinare și creșterii rezistenței la acțiunea vântului și a zăpezii;

iii) Realizarea unor lucrări intense de rărire prin operațiunile de curățiri și rărituri, astfel incât la vârsta de 25 -30 de ani arboretele din zone vulnerabile să nu depășească numărul de 1.000 -1.500 de exemplare la hectar; menținerea unei densități ridicate determină coeficienți de zveltețe mari, de regulă peste 100 , coroane scurte și un risc de rupere sau dezrădăcinare maxim;

iv) După vârsta de 60 de ani, arboretele trebuie conduse prin rărituri forte la intervale mari de 10-15 ani.

v) Recoltarea înainte de vârsta vulnerabilitătii maximei care este la $90-100$ de ani, poate determină reducerea masivă a pierderilor prin declasarea lemnului rupt și calamitat de vânt pe de o parte și a costurilor de exploatare a lemnului din doborâturi pe de altă parte.

11. 0, brad frumos! 0, tempora! Se observă un declin al acestei specii monumentale ca arie de răspândire, dar și din punct de vedere al calității. De ce nu-i mai stă bine acestei specii în pădurile României?

Acestei specii îi stă bine în România. Bradul ocupă circa 5\% din suprafața pădurilor țării și deoarece apare în păduri amestecate împreună cu fagul și molidul, suprafața pe care întâlnim bradul în țara noastră este de peste 600 de mii de hectare. Specia, așa cum o cunosc silvicultorii, este deosebit de sensibilă, în sensul că se regenerează sub masiv, deci la adăpostul arborilor bătrâni, că preferă structurile diversificate atât sub raportul compoziției, cât și sub raportul stratificării verticale și suferă în cazul aplicării tăierilor rase.

În ultima sută de ani, tăierile dominante în pădurile țării noastre au fost cele rase și cvasirase care au supus bradul la grea încercare. Capacitatea acestei specii de reacție la modificarea tratamentelor este impresionantă. Odată cu trecerea la adoptarea unor tratamente cu perioadă lungă de regenerare, tratamentul tăierilor succesive, tratamentul tăierilor progresive, al tăierilor combinate și succesive la margine de masiv, înregistrăm o creștere substanțială a ponderii bradului în compoziția noilor generații de pădure. Este adevărat, în perioada anilor 1970 -1990, pădurile de brad din Europa, dar şi din România au trecut printr-o mare criză, determinată de poluarea generalizată la nivelul întregului continent. Se cunoaște că poluarea nu are limite și urmare a unei politici de dezvoltare bazată pe utilizarea energiilor din arderea combustibililor fosili, poluarea în aer, în sol și în ape devenise o mare problemă. Bradul, mimoza pădurilor europene, a fost cel mai afectat pe suprafețe întinse. În 1991 am publicat cartea „Moartea bradului-un simptom al degradării mediului" unde cititorii noștri găsesc detalii interesante. Creșterile arborilor de brad s-au redus îngrijorător timp de câteva decenii, astăzi asistăm la o revigorare a pădurilor de brad, iar grija silvicultorilor pentru viitor garantează că de această specie se vor bucura și generațiile viitoare.

12. Asistăm la campanii mai mult sau mai puțin susținute de dovezi prin care se blamează silvicultura românească, metodele folosite, iar silvicii sunt puși la zid fără ca replica acestora să fie pe măsură. Unde credeți că este "fractura" și ce anume ar trebui să se întâmple ca adevărul să fie scos din pădure.

$\mathrm{Da}$, și eu sunt de acord că există o campanie 
de denigrare a corpului silvic, o campanie de minimizare a efortului pe care generații de silvicultori 1-au făcut pentru a păstra pădurile în starea pe care o avem astăzi și aș putea spune că în mare parte această campanie este determinată și de o anumită invidie.

În anii "socialismului biruitor" exista sintagma că "tot românul se pricepe la fotbal și la agricultură". Au trecut vremurile și astăzi tot românul, mai ales românul ziarist și ONG-ist se pricepe la protejarea ursului și la reclamarea defrișărilor. Din păcate, această campanie este susţinută de mass-media care, sistematic, invită nespecialiști, reprezentanți ai unor ONGuri, care își fac un țel din denigrarea slujitorilor pădurii. Dacă aceste dezbateri ar fi echilibrate și aşa cum spune adagiul latin "audiatur et altera pars" adică ar fi ascultați și silvicultorii, probabil că adevărul s-ar afla mai lesne. Faptul că România, cu toate dificultățile prin care a trecut în ultimele secole, cuantificate în presiunea enormă asupra pădurilor, are încă o rezervă importantă de păduri virgine neafectate de factorul antropic se datorează grijii cu care generațiile de silvicultori au păstrat aceste crâmpeie de natură nederanjată, pentru a vedea și a compara ce e bine și ce e rău în pădurile artificializate și gestionate pe baze moderne. În majoritatea țărilor europene astfel de păduri virgine, în care procesele naturale și întregul lanţ trofic şi de biodiversitate este conservat integral, lipsesc. Ne-am obișnuit ca să primim lecții de gestionare a pădurilor virgine de la cei care nu le mai au. Ne-am obișnuit să primim lecții de gestionare a carnivorelor mari de la cei care au eradicat ursul, lupul și râsul încă de acum mai bine de 200 de ani. Și, din păcate, suportăm cu stoicism aberații la care reprezentantei noștri în Europa nu sunt în stare să le opună critici și să susțină adevărul și soluțiile de bun simț ale unei bune conviețuiri a omului cu natura, aici în Carpați. (recent am aflat că "Maica Europa" nu ne mai permite să hrănim porcii cu lături - mă întreb, nu le putem arunca peste cineva !?). Ne-am obişnuit, în ultimii 80 de ani, să primim soluțiile în plic fie de la Mos- cova, fie de la Bruxelles și să facem sluj la programe jenante, dar finanțate cu bani europeni. E timpul să fim demni și să trimitem la negocieri experți determinați, cu coloană vertebrală.

13. Ați avut și o prestigioasă și lungă carieră și în învățământul universitar, în paralel cu cercetarea. Sunt temeri că tinerii nu mai apreciază atât de mult laborioasa și facinanta lume a științei, alegând mai degrabă munca în producție. Care ar fi momelile care ar trebui folosite pentru ca noi savanți să vă calce pe urme?

Concomitent cu activitatea de cercetare științifică am avut și o activitate didactică. În perioada dintre anii 1977 până prin 1990 am fost invitat să predau cursuri la Liceul Silvic şi, ulterior, la Școala Tehnică Silvică din Câmpulung. Am simțit că rezultatele cercetărilor trebuie comunicate şi trebuie comunicate direct noilor vlăstare ale silviculturii. După 1990, când prin strădania fostului nostru director, profesorul Radu Ichim, s-a înființat Facultatea de Silvicultură la Universitatea ,Ștefan cel Mare" din Suceava, am fost invitat să predau câteva cursuri, fără însă a mă titulariza. Am predat pe rând, genetică ecologică, metodologia cercetării științifice, ecologia peisajelor și certificarea pădurilor. Munca cu studenții este interesantă și întotdeauna am considerat că este un beneficiu dublu. În ultimii 18 ani a fost invitat să predau cursul „Managementul ecosistemelor naturale" la Universitatea Alexandru Ioan Cuza din Iași, la Facultatea de Geografie, în cadrul unui program de masterat "Mediul actual și dezvoltarea durabilă”. Am putut, astfel, lua pulsul noii generații și pot spune că, din păcate, interesul noii generații pentru cercetare, pentru descoperirea adevărului este din ce în ce mai scăzut. Tinerii sunt convinși că toate răspunsurile se află în Google, că toate adevărurile vin de undeva, cel mai adesea de la Bruxelles sau din America. Niciodată nu a fost o abundență de tineri care să dorească să facă cercetare. Cauzele sunt multiple, iar salariile mici și lipsa unor compensaţii pe care colegii din producție le au por reprezenta o explicație. $\mathrm{Nu}$ am observat decât în foarte rare cazuri și 
atunci interesat, dorința de perfecționare și de investigare a unor fenomene, procese pentru care nu avem încă răspunsuri şi din această cauză pot spune că sunt puțin îngrijorat în legătură cu soarta științelor silvice. Sper însă că această perioadă de oportunism, în care tinerii cercetători umblă să-și umfle CV-ul cu publicații ISI, va trece și lumea românească se va trezi și va redescoperi fascinația gândirii proprii.

14. Imediat după schimbarea de regim din 1989, ați fost managerul Agenției de Protecția Mediului din Suceava. Sunt mari diferențele între mediul de atunci și cel de astăzi? Ce anume strică echilibrul?

După revoluția din decembrie 1989 s-a înfiinţat Ministerul Mediului, iar secretar de stat pentru păduri a fost numit colegul nostru de Institut, dr. ing. Nicolae Geambașu. Domnia sa dorea să aibă în echipă colegi cunoscuți și m-a recomandat ministrului de atunci, profesorul Simion Hâncu, pentru o funcție importantă în Ministerul Mediului. Nu am putut rămâne mult timp în București și la înființarea structurilor teritoriale de Protectia Mediului am fost numit director al Agenției de Protecția Mediului de la Suceava. Aceasta era o structură hibridă care prelua în mare parte atribuțiile fostei OGA (Oficiul de Gospodărire a Apelor) și pot spune că nu a fost ușoară realizarea unei echipe unite și omogene pentru un domeniu atât de nou cum era știința și supravegherea mediului înconjurător. Având relații în minister și în Europa am putut realiza un program important de formare a cadrelor care aveau contingență cu mediul de la Agențiile de Protecția Mediului, de la întreprinderi cu probleme deosebite de mediu și din Universități, cu scopul de a vorbi un limbaj comun și de a grăbi rezolvarea problemelor stringente, existente la vremea respectivă. Astfel, în relație cu Institutul European de Ecologie de la Metz (Franța) am organizat două programe de formare în perioada 1992-1993 în România și în Franța la care au participat 40 de specialiști din ambele țări. Programul intensiv de formare a avut un impact major asupra celor care 1-au frecventat. Din păcate, schimbările rapide survenite în conducerea
Ministerului Mediului a făcut ca aplicarea soluțiilor privind Supravegherea și Protecția Mediului să eșueze lamentabil. Lipsa voinței politice, precum și lipsa de fermitate în aplicarea legii, desele schimbări și promovarea pe criterii politice a cadrelor de conducere explică aceasta situație de indecizie, generalizată în țara noastră. Observați că astăzi, impactul pe care îl au, atât Agențiile de Protecția Mediului, cât și Garda de Mediu sunt mult diminuate și cu efecte slabe în ceea ce privește creșterea calității mediului.

\section{0 săptămână ministru al Mediului, Apelor și Pădu- rilor. Nominalizați, vă rog, trei priorități. Competență. Fermitate. Eficiență.}

\section{Abstract. Ion Barbu: "Our forests have been man- aged in such a way that biological diversity has been maintained at maximum levels. In the Carpathians, there are perhaps the only forests in Europe where the trophic pyramid and the presence of all life forms have remained undisturbed."}

Ion Barbu was born, 69 years ago, in the heart of the Danube Delta, in the village of Sarinasuf, graduating, as head of promotion, the Faculty of Forestry from Brassov, in 1971. Since then, with small exceptions, he has worked in scientific research at the Resort Experimental of Spruce Culture from Câmpulung Moldovenesc. He has published more than 100 scientific articles, books and monographs in prestigious international journals and publications. A university teacher with personality, Ion Barbu led and coordinated numerous international research projects. Doctor in forestry, since 1982, he knows English, German and French.

Ion Barbu should be considered as the scientific researcher who has the will to truth, and can be easily perceived as a surgeon of Romanian forestry. Critical, demanding, very realistic, the teacher is not shy to show the tumor and insist on removing it. It also presents solutions, a remarkable fact, nowadays, even for forestry specialists who are still looking for culprits rather than solutions.

According to his opinion, the Romanian forest, due to its great diversity and high degree of naturalness - compared to the forests of other European 
countries - has a great potential and a special genetic value. The biggest threat is the pursuit of the main raw material produced by the forest, wood, the only assortment requested by foreign companies being high quality wood, timber, all other forest products no longer in demand, due to the destruction of the local wood industry which, in the past, also capitalized on the lower assortments. This has led not only to a drastic reduction in jobs, but also to a low return on the forest economy as a whole, with the share of the forest economy in GDP declining about five times in the last 30 years. In fact, the ecosystem services generated by the forest are not exploited to their full potential, being far from the time when they will be paid in any way. For example, no one has yet paid a penny for the major hydrological service that forests provide for the benefit of those who have become masters of electricity production in our country. Moreover, the owners of forests, whose areas fall in the strictly protected areas of national parks and natural parks in our country, have not been compensated in any way. Unfortunately, in recent years there has been a degradation of the technicality and technologies used in forest exploitation, instead of cable installations being used mainly tractors, with destructive impact on the soil, seedlings and remaining trees. Last but not least, today, a large part of the media and certain non-governmental organizations have made a goal of denigrating the forest servants. But if foresters were also listened to, the truth would probably be easier. The fact that Romania still has an important reserve of primary forests, unaffected by the anthropogenic factor, is due to the care of generations of foresters. In most European countries, such forests are lacking, and international tests of species origin show that the ecotypes in our country can be used successfully in the ecological reconstruction of large forest areas in Central and Western Europe. The export of genetic material from our country can prove to Europe the superiority of Romanian forest management solutions, says Ion Barbu.

Fascinated by the forests-galleries of willows and poplars of childhood, wanting to know other forests, Ion Barbu came to discover the diversity of forests, enough to transform his entire existence. Curious and, at the same time, wise, Ion Barbu excels in seeing the forest beyond good and evil, always remaining in the outposts of knowledge, but also a fan of its dissemination. According to his opinion, the future of Romanian forestry means: Competence. Firmness. Efficiency.

Author. Ciornei Laurențiu (laurentiu.ciornei@ince. ro) - Center for Study and Research for AgroForestry Biodiversity/Romanian Academy, 13, Calea 13 Septembrie, 050711, Bucharest, Romania. 